\title{
PEMBELAJARAN DIRUMAH DALAM LINGKUNGAN KELUARGA DI TENGAH PANDEMI COVID 19
}

\author{
Jumliadi Jumliadi ${ }^{1}$, Zakirah Zakirah ${ }^{2}$, Muhmmad Arsyam ${ }^{3}$, Andi Muhammad Shaleh Alwi ${ }^{4}$, \\ Muhammad Fadhil ${ }^{5}$ \\ ${ }^{1}$ Sekolah Tinggi Agama Islam (STAI) Darul Dakwah Wal-Irsyad (DDI) Kota Makassar, \\ Indonesia \\ E-mail: jumliadimh@gmail.com \\ ${ }^{2}$ Institut Agama Islam Negeri (IAIN) Sultan Amai Gorontalo, Indonesia \\ E-mail: zakirahira17@gmail.com \\ ${ }^{3}$ Sekolah Tinggi Agama Islam (STAI) Darul Dakwah Wal-Irsyad (DDI) Kota Makassar, \\ Indonesia \\ E-mail: arsyam0505@gmail.com \\ ${ }^{4}$ Sekolah Tinggi Agama Islam (STAI) Darul Dakwah Wal-Irsyad (DDI) Kota Makassar, \\ Indonesia \\ E-mail: aleahm4d@gmail.com \\ ${ }^{5}$ Sekolah Tinggi Agama Islam (STAI) Darul Dakwah Wal-Irsyad (DDI) Kota Makassar, \\ Indonesia \\ E-mail: muhammadfadhilyns@gmail.com
}

\begin{abstract}
The government, in dealing with the Corona Virus Disease (Covid-19) pandemic, has set new policies, such as isolation, social and physical distancing, and large-scale social restrictions (PSBB) that keep people staying, working, worshiping, and studying at home. This study aimed to analyze learning at home in a family environment during the pandemic. The method used was ex-post facto. The causes of the naturally occurring variables were reviewed. The population in this study was all students of the Islamic Religious Education Study Program (PAI) of STAI DDI of Makassar City, as many as 225 students, from which 26 (from semester VI) were taken as the sample using a simple random sampling technique. The results of this research with descriptive statistical analysis and inferential statistical analysis showed that the normality test of the learning-at-home activities showed a value of 1.025 and that of the family environment showed a value of 2.131 ( $\mathrm{sig}>\alpha$, normal distribution), the homogeneity test results showed a value of 1.412 ( $\mathrm{sig}>\alpha$, homogeneous), the linearity test results showed a value of 0.986 ( $\operatorname{sig}>\alpha$, linear), and the activeness and the results of the hypothesis test with the correlation test showed a sig value of 0.023 , with the criteria of $\operatorname{sig}(0.023)$ of $<\alpha(0.05)$. Finally, this study concluded that there are learning at home in the family environment amid the COVID-19 pandemic.
\end{abstract}

Keywords: learning at home, family environment, COVID-19 pandemic

Abstrak. Kebijakan pemerintah ditengah pandemi Corona Virus Disease (Covid-19) seperti isolasi, social and physical distancing dan pembatasan sosial berskala besar (PSBB) sehingga masyarakat tetap stay at home, bekerja, beribadah dan belajar di rumah. Oleh karena itu penelitian ini bertujuan untuk menganalisis pengaruh pembelajaran dirumah dalam lingkungan keluarga di tengah pandemic covid 19. Metode yang diguanakan explanatory. variabel yang menjelaskan suatu fenomena tertentu. Populasi dalam penelitian ini yakni seluruh mahasiswa program studi S1 hukum keluarga (Ahwal Syakhshiyah) STAI DDI Kota Makassar yang terdiri 225 mahasiswa, dengan teknik simple random sampling sampel yakni 26 mahasiswa (semester VI). Hasil penelitian dengan analisis statistic deskriptif dan analisis statistic inferensial menunjukkan dengan hasil uji normalitas pembelajaran dirumah 1,025 dan lingkungan keluarga 2,131 ( $\operatorname{sig}>\alpha$, berdistribusi normal), hasil uji homogenitas adalah 1.412 ( $\operatorname{sig}>\alpha$, homogen), hasil uji linearitas adalah 0,986 ( $\operatorname{sig}>\alpha$, linier) dan hasil uji hipotesis dengan uji korelasi menunjukkan nilai sig 0,023, dengan kriteria Sig $(0,023)<\alpha(0,05)$. Akhirnya, penelitian ini menyimpulkan bahwa terdapat pengaruh pembelajaran dirumah dalam lingkungan keluarga di tengah pandemic covid 19.

Kata Kunci : Pembelajaran dirumah, lingkungan keluarga, pandemic covid 19 


\section{Pendahuluan}

Menteri pendidikan dan kebudayaan (mendikbud) nadiem anwar makarim menerbitkan surat edaran nomor 4 tahun 2020 Pada tanggal 24 maret 2020, tentang pelaksanaan pendidikan dalam masa darurat Coronavirus Disease (covid 19). Kebijakan tersebut diantaranya isolasi, social and physical distancing dan pembatasan sosial berskala besar (PSBB) sehingga masyarakat tetap stay at home, bekerja, beribadah dan belajar di rumah. Proses belajar dilaksanakan di rumah melalui pembelajaran daring/jarak jauh dilaksanakan dalam lingkungan keluarg bahan melalui bimbingan orang tua.

(Kementerian Agama RI) dalam Al-Qur'an Surah Al-An'am ayat 38 Islam sebagai agama yang lengkap (kaffah) yang ajarannya meliputi berbagai aspek, sehingga memberikan solusi terhadap keadaan lingkungan ditengah pandemic covid 19, harus tawakkal dan mendekatkan diri kepada Allah SWT. Hadits sebagai sumber ajaran ke dua dalam Islam setelah Al-Qur'an memiliki norma lengkap yang mengatur atau meberikan petunjuk praktis kepada pemeluk agama Islam dalam menghadapi berbagai wabah termasuk pandemi Covid-19 ini (Arifin, 2020). Ditengah pandemic covid 19 ini tetap dirumah, bekerja, beribadah dan belajar di rumah (dalam lingkungan keluarga).

Pendidikan Agama Islam di tengah pandemi Covid-19 yang dilaksanakan dengan isolasi dan pembelajaran jarak jauh dengan memanfaatkan aplikasi teknologi informasi merupakan pengejatawantahan dari pemeliharaan diri (Basri, 2020). Pendidikan dalam lingkungan keluarga ditengah pandemic covid 19, dimana pembelajaran dilakukan secara daring atau pembelajaran jarak jauh dengan menggunakan alat teknologi komunikasi dan informasi, sesui dengan aturan pemerintah. Hal ini sejalan dengan Sekolah Tinggi Agama Islam Darud da'wah Wal Irsyad (STAI DDI) Kota Makassar, yang menggunakan berbagai macam aplikasi pembelajaran khususnya pada program studi S1 hukum keluarga (Ahwal Syakhshiyah) seperti zoom, google clas room, google meat, whats App, aplikasi pembelajaran STAI DDI dan lain sebaginya.

Pembelajaran yang dilasanakan dengan menggunakan pembelajaran daring/jarak jauh dengan melalui bimbingan orang tua. Menurut Dewi (2020) pembelajaran daring merupakan pemanfaatan jaringan internet dalam proses pembelajaran. Dengan pembelajaran daring siswa memiliki keleluasaan waktu belajar, dapat belajar kapanpun dan dimanapun.

Sedangkan menurut khasanah (20210) menyatakan bahwa pembelajaran melalui jaringan memiliki potensi-potensi, antara lain: kebermaknaan belajar, kemudahan mengakses, dan peningkatan hasil belajar. Dalam konteks belajar secara online, mahasiswa dapat berhubungan secara cepat dan langsung dengan teks, gambar, suara, data, dan video dua arah, dengan bimbingan pengajar. Tutorial tatap muka diganti dengan 
perantara teknologi ditengah mewabahnya covid-19, dengan demikian peneliti menganalisis pengaruh pembelajaran dirumah dalam lingkungan keluarga di tengah pandemic covid 19.

\section{Metode}

Penelitian ini merupkan jenis penelitian explanatory dengan pendekatan kuantitatif. penelitian explanatory adalah penelitian yang bertujuan menelaah kausalitas antar variabel yang menjelaskan suatu fenomena tertentu untuk menjelaskan atau membuktikan hubungan atau pengaruh antar variabel melalui pengujian hipotesis (kurniawan, 2012). Sedangkan pendekatan data kuantitatif adalah semua informasi atau data yang diperoleh diwujudkan dengan angka. Dengan demikin variabel bebas (independent variable) dalam penelitian ini adalah lingkungan keluarga ditengah pandemic covid 19 (X) dan variable terikat (dependent variable) pembelajaran dirumah (Y).

Desain Penelitian Desain penelitan hubungan antar variabel bebas dengan variabel terikat digambarkan sebagai berikut :

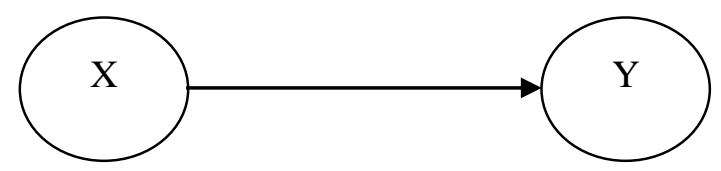

Keterangan:

$\mathrm{X}$ : Lingkungan keluarga ditengh pandemic covid 19

Y : Pembelajaran dirumah

Penelitian ini dilaksanakan di Sekolah Tinggi Agama Islam Darud da’wah Wal Irsyad (STAI DDI) Kota Makassar. Populasi dalam penelitian ini yakni seluruh mahasiswa program studi S1 hukum keluarga (Ahwal Syakhshiyah) STAI DDI Kota Makassar yang terdiri 225 mahasiswa, dengan teknik simple random sampling, sampel yakni 26 mahasiswa (semester VI).

Metode yang digunakan dalam penelitian ini analisis statistic deskriptif dan analisis inferensial yaitu:

\section{Analisis deskriptif}

Metode analisis deskriptif merupakan suatu metode analisis dimana data yang diperoleh dideskripsikan. Variable yang diungkap dalam penelitian ini adalah lingkungan keluarga ditengah pandemic covid 19 dan pembelajaran dirumah pada mahasiswa semester VI program studi S1 hukum keluarga (Ahwal Syakhshiyah) STAI DDI Kota Makassar. 
Data hasil angket dianalisis menggunakan statistik deskriptif. Kriteria pengkategorian yang digunakan untuk mendeskripsikan, dengan kriteria sangat baik, baik, cukup, kurang dan kurang sekali yang ditetapkan oleh departemen pendidikan dan kebudayaan sebagai berikut.

Tabel : Kategori Hasil Angket

\begin{tabular}{cc}
\hline Interval Skor & Kategori \\
\hline $85-100$ & Sangat Baik \\
$70-84$ & Baik \\
$55-69$ & Cukup \\
$46-54$ & Kurang \\
$0-45$ & Kurang Sekali \\
\hline
\end{tabular}

\section{Analisis Inferensial}

Sebelum melakukan uji korelasional (uji hipotesis) terlebih dahulu melaui uji Prasyarat statistik meliputi uji normalitas, uji homogenitas dan uji linearitas.

a. Uji Normalitas

Data terdistribusi normal dapat dilihat dari nilai signifikansi. Pedoman pengambilan keputusan adalah jika nilai signifikan $<0,05$ data tidak normal dan sebaliknya jika nilai signifikansi $>0,05$ data dikatakan normal . Uji kenormalan distribusi data yang digunakan adalah uji Kolmogorov Smirnov dengan menggunakan bantuan SPSS.

b. Uji Homogenitas

Uji Homogenitas data bertujuan untuk melihat tingkat homogen dengan asumsi bahwa data homogen dengan melihat Levene's Test for Equality of Variance pada software SPSS dengan kriteria pengujian yang digunakan adalah sig $>\alpha$ dengan taraf $\alpha=0,05$.

c. Uji Linearitas

Uji linieritas dilakukan untuk mengetahuai apakah dua variabel memiliki hubunagan yang linier atau tidak, pada software SPSS dengan kriteria pengujian data dinggap linear jika P sig pada tabel Anova untuk Deviation from Linearity lebih dari Alpha 0,05.

d. Uji Linearitas

Uji linieritas dilakukan untuk mengetahuai apakah dua variabel memiliki hubunagan yang linier atau tidak, pada software SPSS dengan kriteria pengujian data dinggap linear jika P sig pada tabel Anova untuk Deviation from Linearity lebih dari Alpha 0,05.

Uji Hipotesis (Uji Korelasi) Untuk melihat pengaruh variabel bebas terhadap variabel terikat digunakan korelasi Pearson Product Moment. Hipotesis penelitin ini adalah : 
H1 = terdapat pengaruh pembelajaran dirumah dalam lingkungan keluarga ditengah pandemic covid 19, dan

Ho $=$ Tidak terdapat pengaruh pembelajaran dirumah dalam lingkungan keluarga ditengah pandemic covid 19.

\section{Hasil dan Pembahasan}

\section{Analisis deskriptif}

\section{a. Lingkungan keluarga ditengah pandemic covid 19}

Pengumpulan data dilakukan dengan menggunakan angket lingkungan keluarga ditengah pandemic covid 19 melalui google foam, maka diperoleh distribusi frekuensi pada tabel berikut :

Tabel : Statistik Hasil Angket lingkungan keluarga ditengah pandemic covid 19

\begin{tabular}{cc}
\hline Statistik & Hasil Angket Lingkungan Keluarga \\
\hline Ukuran sampel & 26 \\
Mean (rata-rata) & 84,88 \\
Median (nilai tengah) & 87,00 \\
Mode & 80,00 \\
Std. Deviasi & 6,49 \\
Varians & 42,18 \\
Rentang & 25,00 \\
Skor terendah & 70,00 \\
Skor tertinggi & 95,00 \\
\hline Jumlah & 2207,00 \\
\hline
\end{tabular}

Berdasarkan tabel diatas menunjukkan bahwa pada hasil angket yang diberikan kepada 26 mahasiswa dengan nilai mean 84,88, median 87,00 dan modus 80,00. Berdasarkan hasil analisis statistik angket lingkungan keluarga ditengah pandemic covid 19 dengan nilai rata-rata berada pada kategori baik.

Diagram hasil angket lingkungan keluarga ditengah pandemic covid 19 dapat dilihat sebagai berikut : 


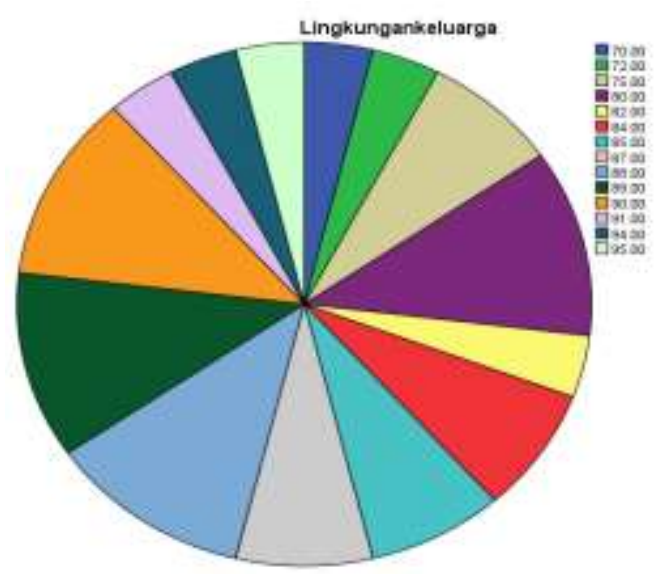

\section{Diagram Lingkungan Keluarga}

Berdasarkan data diatas menunjukkan hasil angket lingkungan keluarga ditengah pandemic covid 19 dengan nilai tertinggi 95,00, nilai terendah 70,00, sehingga lingkungan keluarga ditengah pandemic covid 19 berada pada kategori baik.

\section{b. Pembelajaran dirumah}

Pengumpulan data dilakukan dengan menggunakan angket pembelajaran dirumah melalui google foam, maka diperoleh distribusi frekuensi pada tabel berikut :

Tabel : Statistik Hasil Angket Pembelajaran di Rumah

\begin{tabular}{cc}
\hline Statistik & Hasil Angket Pembelajaran di Rumah \\
\hline Ukuran sampel & 26 \\
Mean (rata-rata) & 81,65 \\
Median (nilai tengah) & 82,00 \\
Mode & 78,00 \\
Std. Deviasi & 6,21 \\
Varians & 38,55 \\
Rentang & 29,00 \\
Skor terendah & 68,00 \\
Skor tertinggi & 97,00 \\
\hline Jumlah & 2123,00 \\
\hline
\end{tabular}

Berdasarkan tabel diatas menunjukkan bahwa pada hasil angket yang diberikan kepada 26 mahasiswa dengan nilai mean 81,65, median 82,00 dan modus 78,00. Berdasarkan hasil analisis statistik angket pembelajaran dirumah dengan nilai rata-rata berada pada kategori baik.

Diagram hasil angket lingkungan keluarga ditengah pandemic covid 19 dapat dilihat sebagai berikut : 


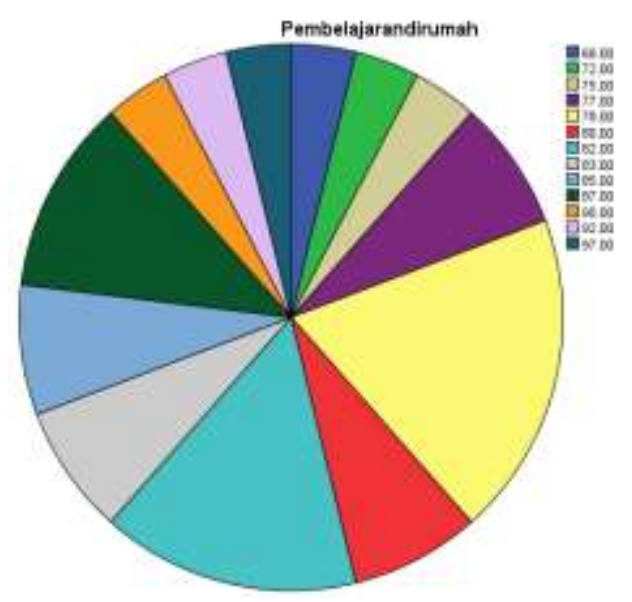

Diagram Pembelajaran Di Rumah

Berdasarkan data diatas menunjukkan hasil angket pembelajaran dirumah dengan nilai tertinggi 97,00, nilai terendah 68,00, sehingga pembelajaran dirumah berada pada kategori baik.

Hasil analisis deskriptif pada angket lingkungan keluarga ditengah pandemic covid 19 berada pada kategori baik dan angket pembelajaran dirumah berada pada kategori baik, hal ini menunjukkan berada pada kategori baik pada pembelajaran dirumah lingkungan keluarga di tengah pandemic covid 19 pada mahasiswa semester VI program studi S1 hukum keluarga (Ahwal Syakhshiyah) STAI DDI Kota Makassar.

\section{Analisis Inferensial}

Analisis inferensial dilakukan untuk menguji pengaruh. Sebelum data di analisis maka terlebih dahulu dilakukan uji prasyarat analisis yaitu uji noramalitas, uji homogenitas dan uji linieritas.

a. Uji normalitas

Data terdistribusi normal dapat dilihat dari nilai signifikansi atau nilai probabilitas. Pedoman pengambilan keputusan adalah jika nilai signifikan $<0,05$ data tidak normal dan sebaliknya jika nilai signifikansi > 0,05 data dikatakan normal.

Uji kenormalan distribusi data yang digunakan adalah uji Kolmogorov Smirnov dengan menggunakan bantuan SPSS, diperoleh nilai Psig untuk variabel pembelajaran dirumah sebesar 1,025, dan lingkungan keluarga 2,131, lebih besar dari 0,05. Dengan demikian dapat disimpulkan bahwa data yang digunakan dalam penelitian berdistribusi normal.

b. Homogen

Data homogenity dapat dilihat dari Levene's Test for Equality of Variance. Pedoman pengambilan keputusan adalah jika nilai Psig < 0,05 data tidak homogeny dan sebaliknya jika nilai Psig > 0,05 data dikatakan homogeny. Hasil uji homogenitas dengan nilai signifikansi $1.412>\alpha$, hal ini menunjukkan data memiliki varian atau homogen.

c. Uji linieritas 
Berdasarkan hasil analisis hasil olah data SPSS diatas maka diperoleh nilai P sig untuk variabel lingkungan keluarga ditengah pandemic covid 19 terhadap pembelajaran dirumah untuk kategori Deviation from Linearity pada tabel Anova yakni 0,986 lebih besar dari Alpha 0,05. Dengan demikian dapat disimpulkan bahwa terdapat hubungan yang linear signifikan antara variabel lingkungan keluarga ditengah pandemic covid 19 terhadap pembelajaran dirumah.

Hasil Uji Hipotesis (uji korelasi) dapat dilihat bahwa pengaruh lingkungan keluarga ditengah pandemic covid 19 terhadap pembelajaran dirumah, menunjukkan nilai sig 0,023, dengan kriteria Sig $(0,023)<\alpha(0,05)$ sehingga $\mathrm{H}_{0}$ ditolak dan $\mathrm{H}_{1}$ diterima.. Akhirnya, penelitian ini menyimpulkan bahwa terdapat pengaruh pembelajaran dirumah dalam lingkungan keluarga di tengah pandemic covid 19.

\section{Simpulan}

Penelitian ini dilaksanakan di Sekolah Tinggi Agama Islam Darud da’wah Wal Irsyad (STAI DDI) Kota Makassar yang terdiri atas semester VI program studi S1 hukum keluarga (Ahwal Syakhshiyah).

Hasil penelitian dengan analisis statistic deskriptif dan analisis statistic inferensial menunjukkan dengan hasil uji normalitas pembelajaran dirumah 1,025 dan lingkungan keluarga 2,131 (sig > $\alpha$, berdistribusi normal), hasil uji homogenitas adalah 1.412 ( $\mathrm{sig}>\alpha$, homogen), hasil uji linearitas adalah 0,986 ( $\operatorname{sig}>\alpha$, linier) keaktifan dan hasil uji hipotesis dengan uji korelasi menunjukkan nilai sig 0,023, dengan kriteria $\operatorname{Sig}(0,023)<\alpha(0,05)$. Akhirnya, penelitian ini menyimpulkan bahwa terdapat pembelajaran dirumah dalam lingkungan keluarga di tengah pandemic covid 19.

\section{Daftar Pustaka}

\section{References}

[1] R. Tosepu, J. Gunawan, D. S. Effendy, H. Lestari, H. Bahar, \& P. Asfian 2020 Correlation between weather and Covid-19 pandemic in Jakarta, Indonesia Science of The Total Environment, 138436

[2] S. Setiati, \& M. K. Azwar 2020 COVID-19 and Indonesia Acta Medica Indonesiana, 52 $184-89$

[3] N. Utaberta, N. Asif, M. T. M. Rasdi, M. Y. M. Yunos, N. A. Ismail, \& S. Ismail 2015 The Concept of Mosque Based on Islamic Philosophy: A Review Based on Early Islamic Texts and Practices of the Early Generation of the Muslims Advances in Environmental Biology, 95 371-375

[4] M. Azhar 2020 Government Strategy in Implementing the Good Governance during COVID-19 Pandemic in Indonesia Administrative Law \& Governance Journal, 32 300-313

[5] M. A. Saloot, N. Idris, R. Mahmud, S. Ja'afar, D. Thorleuchter, \& A. Gani 2016 Hadith data mining and classification: a comparative analysis Artificial Intelligence Review, 46 113-128

[6] M. Yusuf, \& I. S. Wekke 2020 Developing Environmental Awareness and Actualizing Complete Piety Based on Quran International Journal of Advanced Science and Technology, 2905 2039-2050

[7] World Health Organization 2020 Coronavirus disease 2019 (COVID-19): situation report, 72 
[8] M. Idris, E. Willya, I. S. Wekke, \& S. Mokodenseho 2020 Peace Resolution in Education and Application on Information and Communication Technologhy International Journal of Advanced Science and Technology. 296 3349-3358

[9] M. B. N. Wajdi, I. Kuswandi, U. Al Faruq, Z. Zulhijra, K. Khairudin, \& K. Khoiriyah 2020 Education Policy Overcome Coronavirus, A Study of Indonesians EDUTEC: Journal of Education And Technology, 32 96-106

[10] H. Yulia 2020 Online Learning to Prevent the Spread of Pandemic Corona Virus in Indonesia ETERNAL (English Teaching Journal), 111

[11] U. Verawardina, L. Asnur, A. L. Lubis, Y. Hendriyani, D. Ramadhani, I. P. Dewi,... \& T. Sriwahyuni 2020 Reviewing Online Learning Facing the Covid-19 Outbreak Journal of Talent Development and Excellence, 12 3s 385-392

[12] I. A. M. S. Widiastuti, I. B. N. Mantra, \& H. Sukoco 2020 Mobile internet-based learning to cultivate students'speaking skill during coronavirus pandemic International Journal of Applied Science and Sustainable Development (IJASSD), 21 6-10

[13] A. Abidah, H. N. Hidaayatullaah, R. M. Simamora, D. Fehabutar, \& L. Mutakinati 2020 The Impact of Covid-19 to Indonesian Education and Its Relation to the Philosophy of "Merdeka Belajar" Studies in Philosophy of Science and Education, $1138-49$

[14] N. Yaman, \& M. Muhlis 2020 Students'social presence and perceived learning toward ccu course in online classroom (An Evaluating of Learning Process during Pandemic Coronavirus) English and Literature Journal, 7 1 61-73

[15] I. Mayer 2015 Qualitative research with a focus on qualitative data analysis International Journal of Sales, Retailing \& Marketing, 49 53-67

[16] J. P. Cornelissen 2017 Preserving theoretical divergence in management research: Why the explanatory potential of qualitative research should be harnessed rather than suppressed Journal of Management Studies, 543 368-383

[17] Næss, P. (2018). Validating explanatory qualitative research: Enhancing the interpretation of interviews in urban planning and transportation research. Applied Mobilities, 1-20.

[18] L. Li, E. Worch, Y. Zhou, \& R. Aguiton 2015 How and Why Digital Generation Teachers Use Technology in the Classroom: An Explanatory Sequential Mixed Methods Study International Journal for the Scholarship of Teaching and Learning, $92 \mathrm{n} 2$

[19] A. S. Berghoff, S. Schur, L. M. Füreder, B. Gatterbauer, K. Dieckmann, G. Widhalm,... \& M. Preusser 2016 Descriptive statistical analysis of a real life cohort of 2419 patients with brain metastases of solid cancers ESMO open, 12 e000024

[20] U. Simonsohn, J. P. Simmons, \& L. D. Nelson 2019 Specification curve: Descriptive and inferential statistics on all reasonable specifications Available at SSRN 2694998

Kurniawan, D. L. 2012. Pengaruh Lingkungan Belajar, Minat Belajar, dan Motivasi Belajar Terhadap Hasil Belajar Siswa pada Mata Pelajaran TIK Kelas X SMA Negeri 01 Kota Mungkid, Magelang. Tesis. (eprints.uny.ac.id>jurnal)

Yurianto, Ahmad, Bambang Wibowo, K. P. (2020). Pedoman Pencegahan Dan Pengendalian Coronavirus Disease (COVID-19) (M. I. Listiana Azizah, Adistikah Aqmarina (ed.)). 